\title{
Effect of ammonium nutrition on uptake and metabolism of nitrate in wheat
}

\author{
H. Breteler and A. L. Smit
}

Department of Soils and Fertilizers, Agricultural University, Wageningen, the Netherlands

Accepted: 9 January 1974

\section{Summary}

One-month old wheat plants grown in $\mathrm{NO}_{3}$ medium were exposed for 2 days to media with 4 meq $\mathrm{NO}_{3}$ and 0 to 4 meq $\mathrm{NH}_{4}$ per litre. In mixed $\left(\mathrm{NO}_{3}+\mathrm{NH}_{4}\right)$ nutrition, $\mathrm{NH}_{4}$ uptake exceeded $\mathrm{NO}_{3}$ uptake even at the lowest $\mathrm{NH}_{4}$ level. Ammonium metabolism also predominated over nitrate assimilation and caused a higher free amino acid content, a lower carboxylate content, and a lower nitrate reductase activity (NRA) in the tops than nitrate alone.

In vitro experiments with desalted cell-free nitrate reductase extracts of wheat tops showed that $\mathrm{NH}_{4}$ ions inhibited NRA, but that a selection of amino acids did not depress NRA.

The drop in NRA in wheat tops caused by $\mathrm{NH}_{4}$ nutrition could not be related to the low level of tissue $\mathrm{NH}_{4}$, nor to any other single factor. It was suggested that changes in the redox situation in the cells are involved.

\section{Introduction}

A still inadequately explained phenomenon in plant nutrition is the severe suppression of $\mathrm{NO}_{3}$ uptake by concomitant $\mathrm{NH}_{4}$ uptake in, for example, perennial ryegrass (Lycklama, 1963), wheat (Minotti et al., 1969) and Chlorella (Syrett \& Morris, 1963). Conversely, the effect of $\mathrm{NO}_{3}$ uptake on $\mathrm{NH}_{4}$ uptake in small.

Weissman (1951) and Lyklama (1963) found that $\mathrm{NH}_{4}$ nutrition affected nitrate reduction rather than nitrate accumulation in the plant. The latter author and Jackson et al. (1973) suggested the existence of an assimilation-linked rate of nitrate uptake.

The present communication deals with the effect of $\mathrm{NH}_{4}$ uptake on uptake and metabolism of nitrate in wheat plants. The additional study of the inhibition of the nitrate reductase activity (NRA) by $\mathrm{NH}_{4}$ nutrition was considered of interest, because those factors associated with $\mathrm{NH}_{4}$ nutrition which actually repress NRA in plants are still unknown.

\section{Materials and method}

Spring wheat seeds (Triticum aestivum cv. Orca) were germinated in quartz sand moistened with demineralized water. The seedlings were transferred to a well-aerated 
Table 1. Composition of the nutrient solutions (meq/litre).

\begin{tabular}{llllllllll}
\hline Medium & $\mathrm{NH}_{4}$ & $\mathrm{Na}$ & $\mathrm{K}$ & $\mathrm{Ca}$ & $\mathrm{Mg}$ & $\mathrm{NO}_{3}$ & $\mathrm{H}_{2} \mathrm{PO}_{4}$ & $\mathrm{SO}_{4}$ & $\mathrm{Cl}$ \\
$\mathrm{NO}_{3}$ & - & - & 6.0 & 2.5 & 4.0 & 6.0 & 1.0 & 2.5 & 3.0 \\
$\mathrm{NO}_{3}+\mathrm{NH}_{4}$ & $0-4.0$ & 1.0 & 3.0 & 2.0 & 1.0 & 4.0 & 1.0 & 1.0 & $1.0-5.0$ \\
\hline
\end{tabular}

Trace elements: $0.5 \mathrm{mg} \mathrm{B}, 0.5 \mathrm{mg} \mathrm{Mn}, 0.4 \mathrm{mg} \mathrm{Fe}, 0.05 \mathrm{mg} \mathrm{Zn,} 0.02 \mathrm{mg} \mathrm{Cu}$ and $0.01 \mathrm{mg} \mathrm{Mo/litre}$. $\mathrm{N}$ serve (2-chloro-6-trichloromethyl pyridine) $0.01 \mathrm{mg} /$ litre was added to the $\left(\mathrm{NO}_{3}+\mathrm{NH}_{4}\right)$ media.

nutrient solution (Table $1, \mathrm{NO}_{3}$ medium), renewed at regular time intervals. After 1 month, the plants were distributed over 5 well-aerated solutions with constant nitrate but different ammonium concentrations of $0,1,2,3$ and 4 meq $\mathrm{NH}_{4} /$ litre (Table 1 , $\mathrm{NO}_{3}+\mathrm{NH}_{4}$ media). The plants grew for 2 days in these media which were renewed 4 times. The plants were grown in the spring of 1972 in a heated greenhouse.

For in vitro determinations, nitrate reductase was extracted from tops of plants remaining on the $\mathrm{NO}_{3}$ medium.

\section{Analytical methods}

Nitrate reductase (E.C.1.6.6.1.) activity was determined according to Sanderson \& Cocking (1964) with a variety of modifications. A sample of tops was excised, immediately taken to a cold room $\left(1^{\circ} \mathrm{C}\right)$ and clipped into small pieces. $2.00 \mathrm{~g}$ were homo. genized together with $25 \mathrm{ml}$ of a cold extraction medium, consisting of $200 \mathrm{ml}$ $0.5 M$ sucrose $+50 \mathrm{ml} 0.1 M$ tris. $\mathrm{HCl}$ buffer $\mathrm{pH} 7.5+25 \mathrm{ml} 0.01 M$ cysteine + $2.5 \mathrm{ml} 0.003 M$ EDTA, having a final $\mathrm{pH}$ of 7.5 to 7.6. A Bühler homogenizer with an ice-water cooled container was used for 30 seconds at $40000 \mathrm{rev} / \mathrm{min}$. The homogenates were centrifuged $\left(15\right.$ minutes, $\left.0^{\circ} \mathrm{C}, 40000 \mathrm{~g}\right)$ and the supernatant filtered through glass-wool. Of this crude enzyme extract $1 \mathrm{ml}$ was pipetted into a centrifuge tube and mixed with $5 \mathrm{ml}$ incubation medium $\left(20 \mathrm{ml} 0.1 M \mathrm{KNO}_{3}+60 \mathrm{ml}\right.$ reduced

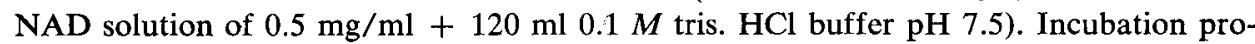
ceeded at $30^{\circ} \mathrm{C}$ for 30 minutes. Nitrate reduction was stopped by placing the tubes in ice-water and adding $1 \mathrm{ml} 1 \%(\mathrm{w} / \mathrm{v})$ sodium lauryl sulphate, $2 \mathrm{ml}$ ice-cold $96 \%(\mathrm{v} / \mathrm{v})$ ethanol and $1 \mathrm{ml} 2 M$ barium acetate. After each addition the tubes were shaken vigorously. The mixture was centrifuged $(20000 \mathrm{~g}, 10$ minutes $)$ and nitrite was determined by mixing the supernatant with $2 \mathrm{ml} 1 \%(\mathrm{w} / \mathrm{v})$ sulphanylamide in $2.5 \mathrm{M} \mathrm{HCl}$ and then with $2 \mathrm{ml} 0.02 \%(\mathrm{w} / \mathrm{v}) \mathrm{N}$-1-naphtylethylene diamine. $\mathrm{HCl}$.

After 30 minutes, the optical density was measured with a Uvichem $H 1620$ spectrophotometer at $540 \mathrm{~nm}$. Standard series of $0-0.3 \mathrm{~m} M \mathrm{KNO}_{2}$ were treated in the same way. The coefficient of variation of the measurements was $\pm 5 \%$.

Gel filtration chromatography of the crude enzyme extracts was used to desalt extracts for in vitro experiments. Through a column $(\varnothing 1.5 \mathrm{~cm})$ of $6.0 \mathrm{~g}$ Sephadex G-25 (medium) $4 \mathrm{ml}$ of crude extract were passed, eluted with extraction medium, and eluate $\mathrm{ml} \mathrm{13-18}$ were collected. This $6-\mathrm{ml}$ fraction contained $98 \%$ of the NRA. The nitrate concentration was $0.05 \mathrm{mM}(0.5 \%$ of the concentration in the crude extract).

Desalted and crude extracts were tested for NRA in the same way.

For methods of determination of carboxylates, free nitrogenous compounds, watersoluble carbohydrates, nitrogen and inorganic constituents, reference is made to Breteler (1973). 


\section{Experimental}

1. Wheat plants grown for 1 month in $\mathrm{NO}_{3}$ medium were exposed to the $\left(\mathrm{NO}_{3}+\mathrm{NH}_{4}\right)$ test media for 2 days. The $\mathrm{pH}$ of the nutrient solution was measured at regular intervals. After exposure the tops were harvested and analysed for NRA, free ammonium ions, amides and amino acids, water-soluble carbohydrates, total $\mathrm{N}, \mathrm{NO}_{3}$, carboxylates, $\mathrm{K}, \mathrm{Na}, \mathrm{Mg}, \mathrm{Ca}, \mathrm{SO}_{4}, \mathrm{Cl}$ and $\mathrm{H}_{2} \mathrm{PO}_{4}$.

In vitro tests with desalted enzyme extracts of wheat tops:

2. The effect of the addition of $\mathrm{NH}_{4}$ ions $\left(0-100 \mathrm{meq} /\right.$ litre as $\left.\mathrm{NH}_{4} \mathrm{Cl}\right)$ to the incubation medium on NRA was tested.

3. The effect of $\mathrm{NH}_{4}$ on NRA was compared with the effect of other cations by substitution of the nitrates of $\mathrm{Na}, \mathrm{Mg}, \mathrm{Ca}$ and $\mathrm{NH}_{4}$ for $\mathrm{KNO}_{3}$ in the incubation medium. 4. The effect of some major amino acids of wheat, glutamine, asparagine, glutamic acid, aspartic acid and $\gamma$-amino butyric acid (Mengel \& Helal, 1970) on NRA was tested by adding these compounds in a concentration of $10 \mathrm{~m} M$ to the incubation medium.

\section{Results}

Experiment 1. Changes in $\mathrm{pH}$ of the nutrient solution during growth on $\left(\mathrm{NO}_{3}+\mathrm{NH}_{4}\right)$ inedia are given in Table 2. With $\mathrm{NH}_{4}$ the $\mathrm{pH}$ dropped so that cation absorption must have exceeded anion absorption even where $\mathrm{NH}_{4}$ constituted only $20 \%$ of all the $\mathrm{N}$ in the medium. This indicates preferential $\mathrm{NH}_{4}$ uptake or inhibited $\mathrm{NO}_{3}$ uptake.

NRA in the tops after 2 days of growth in $\left(\mathrm{NO}_{3}+\mathrm{NH}_{4}\right)$ media (Fig. 1) decreased with $\mathrm{NH}_{4}$ concentration and $\mathrm{NH}_{4}$ uptake by ultimately $77 \%$.

A similar decrease in NRA by $\mathrm{NH}_{4}$ was found by Smith \& Thompson (1971a) for excised barley roots and Joy (1969) for Lemna minor.

Fig. 2 shows the carboxylate content of the tops. Their sum decreased with increasing $\mathrm{NH}_{4}$ concentration mainly by a decrease in citrate, succinate and malate. The drop indicates that in $\left(\mathrm{NO}_{3}+\mathrm{NH}_{4}\right)$ nutrition assimilation of ammonium predominated over the assimilation of nitrate since substitution of ammonium for nitrate is known to reduce the accumulation of carboxylates.

Table 2. Change in nutrient solution $\mathrm{pH}$ caused by wheat plants after 16 hours growth in $\left(\mathrm{NO}_{3}+\mathrm{NH}_{4}\right)$ media. The initial $\mathrm{pH}$ is the average of 5 fresh media (range 5.17 5.46).

\begin{tabular}{ll}
\hline Medium & $\mathrm{pH}$ \\
& \\
Initial & 5.31 \\
$4 \mathrm{NO}_{3}+\mathrm{ONH}_{4}$ & 7.18 \\
$4 \mathrm{NO}_{3}+1 \mathrm{NH}_{4}$ & 3.72 \\
$4 \mathrm{NO}_{3}+2 \mathrm{NH}_{4}$ & 3.38 \\
$4 \mathrm{NO}_{3}+3 \mathrm{NH}_{4}$ & 3.07 \\
$4 \mathrm{NO}_{3}+4 \mathrm{NH}_{4}$ & 3.17 \\
\hline
\end{tabular}




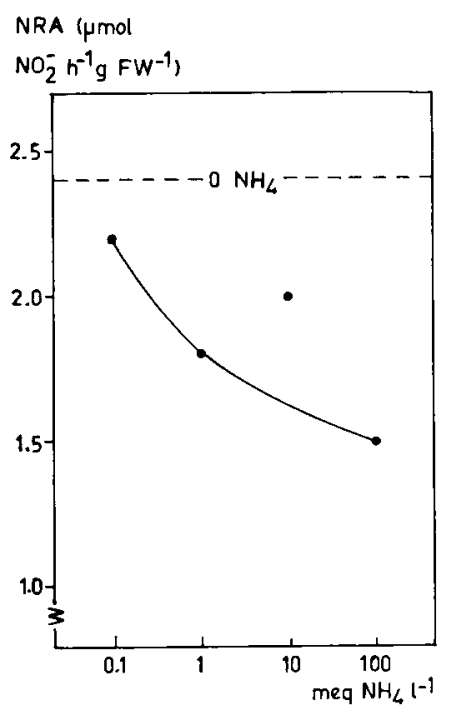

Fig. 1. The effect of two days of mixed $\left(\mathrm{NO}_{3}+\mathrm{NH}_{4}\right) \mathrm{nu}-$ trition on the NRA of the tops. Experiment 1 .

Fig. 3 shows that ammonium increased the concentration of free amino acids and amides in the dry matter and as $\%$ of total $\mathrm{N}$. $\mathrm{NH}_{4}$ accumulated in the tops of $\mathrm{NH}_{4}$-fed plants at a highest value of $26 \mathrm{meq} / \mathrm{kg} \mathrm{DM}$, whilst with nitrate alone the plants contained $18 \mathrm{meq} / \mathrm{kg}$ DM.

Fig. 4 shows that increased $\mathrm{NH}_{4}$ uptake decreased the total inorganic cation content (C) more than the total inorganic anion content (A). The resulting drop in (C-A) followed closely the decrease in carboxylate content (Fig. 2). Changes in $\mathrm{C}$ and A were mainly

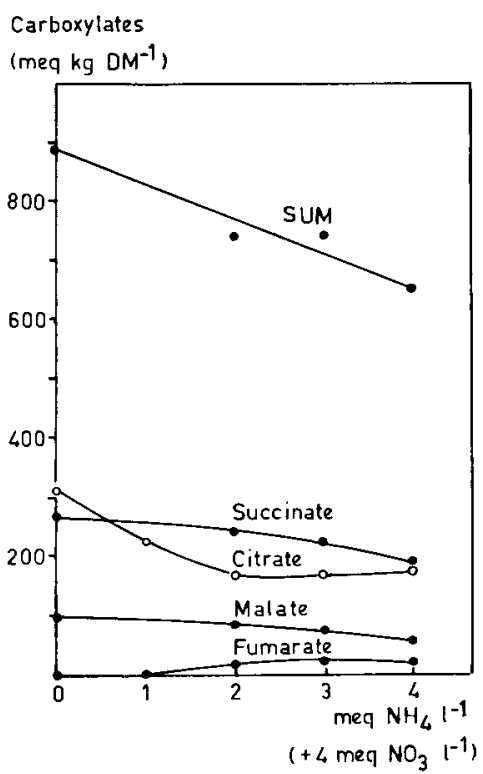

Fig. 2. The effect of two days of mixed $\left(\mathrm{NO}_{3}+\mathrm{NH}_{4}\right)$ nutrition on the carboxylate content of the tops. Experiment 1 . 


\section{EFFECT OF AMMONIUM NUTRITION ON UPTAKE AND METABOLISM OF NITRATE IN WHEAT}

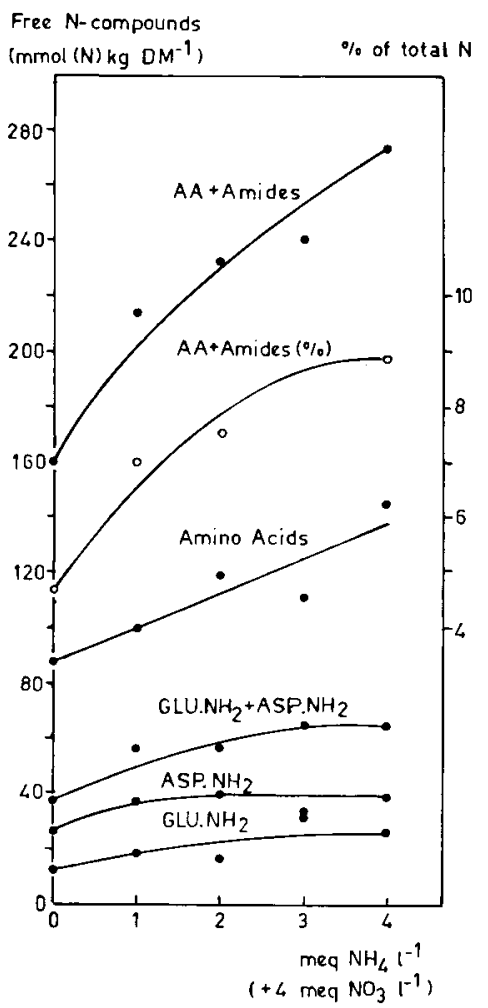

meq $\mathrm{kg} \mathrm{DM-1}$

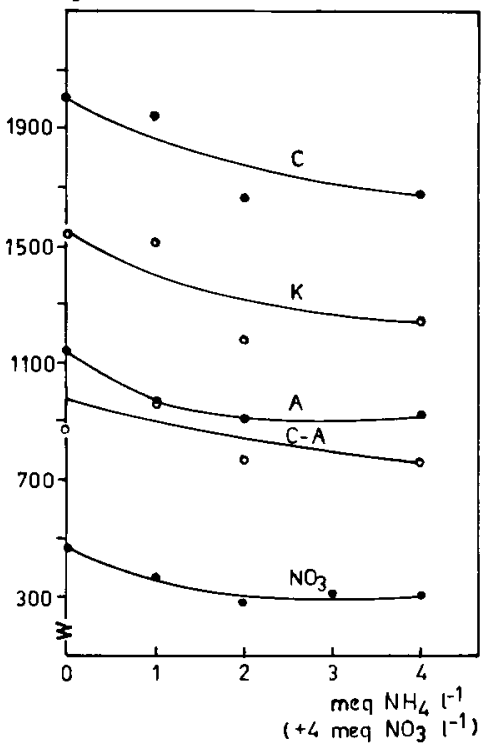

Fig. 3. The effect of two days of mixed $\left(\mathrm{NO}_{3}+\mathrm{NH}_{4}\right)$ nutrition on the contents of some free nitrogenous compounds in the tops. Amides and amino acids in $\mathrm{mmol} / \mathrm{kg}$ DM, sum of amides and amino acids in mmol $\mathrm{N} / \mathrm{kg} \mathrm{DM}$ or as $\%$ of total $\mathbf{N}$ (right hand ordinate). Experiment 1.
Fig. 4. The effect of two days of mixed $\left(\mathrm{NO}_{3}+\mathrm{NH}_{4}\right)$ nutrition on the contents of inorganic cations $(C=N a$ $\left.+\mathrm{K}+\mathrm{Mg}+\mathrm{Ca}+\mathrm{NH}_{4}\right)$, inorganic anions $(\mathrm{A}=\mathrm{Cl}$ $\left.+\mathrm{H}_{2} \mathrm{PO}_{4}+\mathrm{NO}_{3}+\mathrm{SO}_{4}\right),(\mathrm{C}-\mathrm{A}), \mathrm{K}$ and $\mathrm{NO}_{3}$ in the tops. Experiment 1. 
due to changes in $\mathrm{K}$ and $\mathrm{NO}_{3}$ content. Potassium was lower, probably as a consequence of competitive inhibition. Decreased nitrate assimilation caused no increase in nitrate accumulation in the tops, because uptake of $\mathrm{NO}_{3}$ was also inhibited. The water-soluble sugar content of the tops increased slightly from 6.4 to $7.4 \%$ of DM with increase in $\mathrm{NH}_{4}$ concentration. This agrees with results of Kirkby (1968) on white mustard. Breteler (1973) found a lower sugar content in sugar-beet plants supplied with ammonium in place of nitrate, but in his experiments $\mathrm{pH}$ of the medium was kept accurately constant. Perhaps, the effect of acidity of the nutrient medium on plant growth is involved.

Experiment 2. Ammonium concentrations up to $100 \mathrm{meq} / \mathrm{litre}$ in the incubation medium decreased NRA by ultimately $38 \%$ in vitro (Fig. 5). As NRA in Experiment 1 (Fig. 1) dropped by $77 \%$ in vivo, whilst the incubated plant extracts contained not more than $0.5 \mathrm{meq} \mathrm{NH}_{4} /$ litre, the decrease in nitrate metabolism in the intact wheat tops could not be due to NRA inhibition by $\mathrm{NH}_{4}$ ions in the tissue.

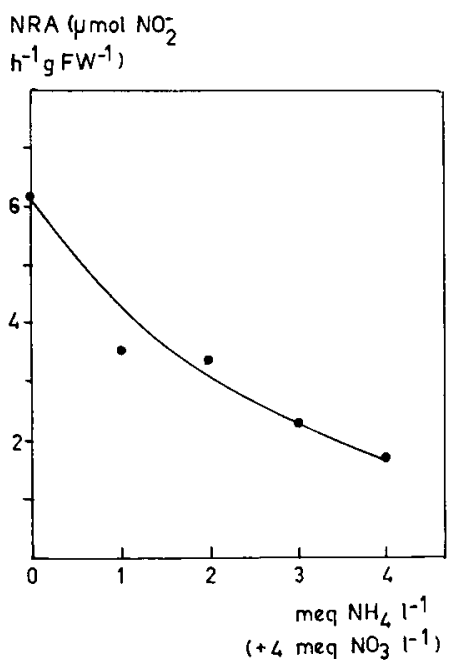

Fig. 5. The effect of the $\mathrm{NH}_{4}$ concentration in the incubation medium on NRA of a desalted extract of wheat tops. The dashed line represents NRA without $\mathrm{NH}_{4}$. Experiment 2.

Experiment 3. Highest in vitro NRA's were obtained with the nitrates of $\mathrm{K}$ and $\mathrm{Na}$ (Table 3). The divalent cations $\mathrm{Ca}$ and $\mathrm{Mg}$ gave lower NRA's, and $\mathrm{NH}_{4} \mathrm{NO}_{3}$ was intermediate in its effect. Compared with the non-desalted crude extract (no GFC) NRA was stimulated only by $\mathrm{K}$ and $\mathrm{Na}$. In the presence of $\mathrm{NH}_{4}$, the NRA was still considerable. Nitsos \& Evans (1966) found the highest induction rate of NR in Neurospora crassa with $\mathrm{K}$ present in the nutrient solution.

Experiment 4 . The presence of some amides and amino acids in the incubation medium (in vitro tests) increased rather than decreased the NRA. Stimulation ranged between $7 \%$ ( $\gamma$-amino butyric acid) and $66 \%$ (asparagine). Apparently, the increased content of free amino acids in the plants grown in $\mathrm{NH}_{4}$ nutrition (Fig. 3), bore no relation to 
Table 3. Effect of several cations on in vitro NRA of a desalted extract of wheat tops. Cations present as nitrates $(10 \mathrm{meq} /$ litre incubation medium). NRA in $\mu \mathrm{mol}$ $\mathrm{NO}_{2}-\mathrm{h}^{-1} \mathrm{gFW}-1$. Bottom line representes NRA of a nondesalted extract.

\begin{tabular}{lr}
\hline Nitrate of & NRA \\
$\mathrm{Ca}$ & 1.5 \\
$\mathrm{Mg}$ & 1.9 \\
$\mathrm{Na}$ & 2.6 \\
$\mathrm{~K}$ & 3.0 \\
$\mathrm{NH}_{4}$ & 2.1 \\
$\mathrm{No}$ GFC & \\
\hline
\end{tabular}

their decreased NRA. Morton (1956) found that amino acids in a casein hydrolysate did not reduce NRA in mould fungi. Smith \& Thompson (1971a, b) found that ammonium and a variety of aminoacids did not affect the in vitro NRA from barley roots and Chlorella, whereas these compounds reduced NR induction in vivo in Chlorella, indicating that NRA per se was not involved.

\section{Discussion}

Data of Experiment 1 prove that $\mathrm{NH}_{4}$ uptake prevailed after 2 days in $\left(\mathrm{NO}_{3}+\mathrm{NH}_{4}\right)$ nutrition. Keeping pace with the ammonium concentration in the nutrient solution, $\mathrm{NH}_{4}$ was also assimilated at a higher rate than $\mathrm{NO}_{3}$.

Concerning plant composition, $\mathrm{NH}_{4}$ assimilation increased free amino acids and amides and decreased carboxylates ( $\mathrm{C}-\mathrm{A}$ ), alkali cations (especially $\mathrm{K}$ ) and $\mathrm{NO}_{3}$ in the tops. The decrease in $\mathrm{K}$ and $\mathrm{NO}_{3}$ in the tissue seems too small to account for the decrease in NRA.

In sugar-beet plants, the contribution of the youngest leaves to the total NRA of the aerial parts was considerable and high NRA in those leaves coincided with low nitrate contents (van Egmond \& Breteler, 1972). Thus, the fall in $\mathrm{NO}_{3}$ uptake and $\mathrm{NO}_{3}$ content in the tops may affect total NRA more than can be accounted for by the decrease in average $\mathrm{NO}_{3}$ content. Data of Experiments 2, 3 and 4 indicate that the activity per se of the investigated enzyme was suppressed by $\mathrm{NH}_{4}$ ions, and not by free amino compounds. However, free $\mathrm{NH}_{4}$ accumulation was low and also occurred in the tops of $\mathrm{NO}_{3}$ plants, although at a still lower level than in plants with additional $\mathrm{NH}_{4}$ in the medium.

Since half-life time of NR is about 4 hours (Beevers \& Hageman, 1969), its synthesis plays an important role in the in vivo activity. Investigations into the effect of $\mathrm{NH}_{4}$ nutrition on NR induction produced variable results. In radish and corn (Beevers et al., 1965; Ingle et al., 1966; Schrader \& Hageman, 1967), perennial ryegrass (Bowerman \& Goodman, 1971) and wheat (Minotti et al., 1969), NR induction was not depressed by $\mathrm{NH}_{4}$ absorption. In a review Filner et al. (1969) concluded that in contrast with 
higher plants, $\mathrm{NR}$ induction in fungi and algae is inhibited by $\mathrm{NH}_{4}$ in the nutrient medium. However, the data of Joy (1969) on Lemna, Smith \& Thompson (1971a) on barley roots and Candela et al (1957) on cauliflower give evidence of decreased NR induction on media containing $\mathrm{NH}_{4}$ in higher plants as well.

The relatively small depressing effect of $\mathrm{NH}_{4}$ ions on enzyme inactivation and the stimulatory effect of amino acids readily synthesized from ammonium are indications of hampered enzyme synthesis during the 2 days of Experiment 1, unless factors associated with other constituents, changed by $\mathrm{NH}_{4}$ nutrition, are involved. One of these could be the change in reducing power in the cells. Kessler (1964) stated that the nitrate reductase activity is linked to all processes that generate reduced pyridine nucleotides. In cotton leaf discs under anaerobiosis, the ratio oxidized: reduced NAD increased from 0.15 to 0.43 as a consequence of $\mathrm{NH}_{4}$ nutrition (Radin, 1973). Mould fungi contained $20 \%$ less $\mathrm{H}$ donors in $\mathrm{NH}_{4}$ medium than in $\mathrm{NO}_{3}$ medium (Morton, 1956). The interaction between $\mathrm{NH}_{4}$ nutrition, oxygen and $\mathrm{NO}_{3}$ reduction in Aerobacter aerogenes (van 't Riet et al., 1968) and in Escherichia coli (Showe \& DeMoss, 1968) suggested the existence of a redox-sensitive repressor which mediates NR regulation. Smith \& Thompson (1971a) also suggest that the supply of reducing power acts as a limiting factor in the $\mathrm{NH}_{4}$ - NRA interaction. All cited data suggest that the influence of nitrogen source on the redox situation is responsible for the regulation of enzymatic nitrate reduction.

Our conclusion is that up till now there is no conclusive evidence that one single factor is responsible for the $\mathrm{NH}_{4}$-induced repression of nitrate reduction in plants.

\section{Acknowledgment}

We wish to thank Mr E. M. Wittich and Mrs Trudy Plug-Hendriks for their assistance during the experiments. Comments on the text by Dr A. C. Schuffelen and Dr A. van Diest are gratefully acknowledged.

\section{References}

Beevers, L., L. E. Schrader, D. Flesher \& R. H. Hageman, 1965. The role of light and nitrate in the induction of nitrate reductase in radish cotyledons and maize seedlings. Pl. Physiol. 40: 691-698.

Beevers, L. \& R. H. Hageman, 1969. Nitrate reduction in higher plants. A. Rev. Pl. Physiol. 20: 495-522.

Bowerman, A. \& P. J. Goodman, 1971. Variation in nitrate reductase activity in Lolium. Ann. Bot. 35: $353-366$.

Breteler, H., 1973. A comparison between ammonium and nitrate nutrition of young sugar-beet plants grown in nutrient solutions at constant acidity 1. Production of dry matter, ionic balance and chemical composition. Neth. J. agric. Sci. 21: 227-244.

Candela, M. I., E. G. Fisher \& E. J. Hewitt, 1957. Molybdenum as a plant nutrient X. Some factors affecting hte activity of nitrate reductase in cauliflower plants grown with different nitrogen sources and molybdenum levels in sand culture. Pl. Physiol. 32: 280-288.

Egmond, F. van \& H. Breteler, 1972. Nitrate reductase activity and oxalate content of sugar-beet leaves. Neth. J. agric. Sci. 20: 193-198.

Filner, P., J. L. Wray \& J. E. Varner, 1969. Enzyme induction in higher plants. Science 165: 358-367.

Ingle, J., K. W. Joy \& R. H. Hageman, 1966. The regulation of activity of the enzymes involved in the assimilation of nitrate by higher plants. Biochem. J. 100: 577-588.

Jackson, W. A., D. Flesher \& R. H. Hageman, 1973. Nitrate uptake by darkgrown corn seedlings Pl. Physiol. 51: 120-127. 
Joy, K. W., 1969. Nitrogen metabolism of Lemna minor. II. Enzymes of nitrate assimilation and some aspects of their regulation. Pl. Physiol. 44: 849-853.

Kessler, E. 1964. Nitrate assimilation by plants. A. Rev. Pl. Physiol. 15: 57-72.

Kirkby, E. A., 1968. Influence of ammonium and nitrate nutrition on the cation-anion balance and nitrogen and carbohydrate metabolism of white mustard plants grown in dilute nutrient solutions. Soil Sci. 105: 133-141.

Lycklama, J. C., 1963. The absorption of ammonium and nitrate by perennial rye-grass. Acta bot. neerl. 12: 361-423.

Marcus, A., 1971. Enzyme induction in higher plants. A. Rev. Pl. Physiol. 22: 313-336.

Mengel, K. \& M. Helal, 1970. The effect of increasing nitrogen supply on the composition of the soluble amino fraction and yield of spring wheat. In: E. A. Kirkby (Ed.), Nitrogen nutrition of the plant, pp. 162-173.

Minotti, P. L., D. G. Williams \& W. A. Jackson, 1969. The influence of ammonium on nitrate reduction in wheat seedlings. Planta (Berl.) 86: 267-271.

Morton, A. G., 1965. A study of nitrate reduction in mould fungi. J. exp. Bot. 7: 97-112.

Nitsos, R. E. \& H. J. Evans, 1966. Effect of univalent cations on the inductive formation of nitrate reductase. Pl. Physiol. 41: 1499-1504.

Radin, J. W., 1973. In vivo assay of nitrate reductase in cotton leaf discs. Effect of oxygen and ammonium. Pl. Physiol. 51: 332-336.

Riet, J. van 't, A. H. Stouthamer \& R. J. Planta, 1968. Regulation of nitrate assimilation and nitrate respiration in Aerobacter aerogenes. J. Bacteriol. 96: 1455-1464.

Sanderson, G. W. \& E. C. Cocking, 1964. Enzymic assimilation of nitrate in tomato plants 1 . Reduction of nitrate to nitrite. Pl. Physiol. 39: 416-422.

Schrader, L. E. \& R. H. Hageman, 1967. Regulation of nitrate reductase activity in corn (Zea mays L.) seedlings by endogenous metabolites. Pl. Psysiol. 42: 1750-1756.

Showe, M. K. \& J. A. DeMoss, 1968. Localization and regulation of nitrate reductase in Escherichia coli. J. Bacteriol. 95: 1305-1313.

Smith, F. W. \& J. F. Thompson, 1971a. Regulation of nitrate reductase in excised barley roots. Pl. Physiol. 48: 219-223.

Smith, F. W. \& J. F. Thompson, 1971b. Regulation of nitrate reductase in Chlorella vulgaris. Pl. Physiol. 48: 224-227.

Syrett, P. J. \& I. Morris, 1963. The inhibition of nitrate assimilation by ammonium in Chlorella. Biochim. biophys. Acta 67: 566-575.

Weissman, G. S. 1951. Nitrogen metabolism of wheat seedlings as influenced by the ammonium: nitrate ratio and the hydrogen ion concentration, $A m$. J. Bot. 38: 162-174. 